\title{
PLONOSIOS ŽARNOS UŽDEGIMINIS MIOFIBROBLASTINIS NAVIKAS: LABAI AGRESYVIOS EIGOS KLINIKINIS ATVEJIS
}

\author{
Gabija Viederyte் $\dot{1}^{1}$, Algirdas Šlepavičius ${ }^{2}$ \\ ${ }^{1}$ Lietuvos sveikatos mokslu universitetas, ${ }^{2}$ Klaipédos universitetiné ligonine
}

Raktažodžiai: uždegiminis miofibroblastinis navikas, plonosios žarnos uždegiminis miofibroblastinis navikas, chirurgija.

\begin{abstract}
Santrauka
Uždegiminis miofibroblastinis navikas (UMN) yra retas neoplastinis pažeidimas esant vietiniam agresyviam augimui ir polinkiui pasikartoti. Ši liga dažniausiai diagnozuojama vaikams, nors gali pasireikšti bet kokio amžiaus žmonėms. UMN gali pažeisti bet kuri organą, tačiau dažniausiai pasitaiko plaučiuose. Simptomai nespecifiniai, priklausomi nuo naviko augimo vietos bei pažeisto organo. Virškinimo sistema retai būna pirminè naviko atsiradimo vieta. Straipsnyje pristatomas 71 metu vyro pirminio plonosios žarnos UMN ir žarnyno nepraeinamumo klinikinis atvejis, kai ligos eiga buvo visiškai nebūdinga šios grupès augliams.
\end{abstract}

\section{İvadas}

Uždegiminis miofibroblastinis navikas, anksčiau vadintas uždegiminiu pseudonaviku ar plazmos ląstelių granuloma, priklauso retų verpstės formos ląstelių pažeidimų klasei, pasireiškiančiai ne visada nuspejjamu biologiniu aktyvumu, kartais linkęs ị aplinkinių audinių invaziją ir vietinị pasikartojimą [1-3]. UMN pirmieji aprašè M. Bahadori ir A. Liebow 1973 metais [4]. Nuo to laiko aprašomi pavieniai ligos atvejai įvairiose organizmo sistemose bet kokio amžiaus pacientams $[5,6]$.

Darbo tikslas - aprašyti retą pirminio plonosios žarnos uždegiminio miofibroblastinio naviko klinikinį atvejị.

\section{Klinikinis atvejis}

71 metų vyras $2020 \mathrm{~m}$. kovo 6 d. stacionarizuotas ị Klaipẻdos universitetinès ligoninès (KUL) vidaus ligų skyrių dèl 3 savaites trunkančio pilvo skausmo epigastriumo ir kairès pilvo pusès dalyje, pilvo apimties didejimo.

Objektyvios apžiūros metu: pilvas minkštas, skausmingas kaireje pusejje. Kairèje pilvo pusèje apčiuoptas darinys (1 pav.). Kitose sistemose pokyčių nerasta. Viršutinèje pilvo organų echoskopijoje stebimi navikiniai dariniai kaireje pilvo pusèje, formuojantys konglomeratą.

Pilvo KT: pilvo kairèje pusèje tarp plonosios žarnos kilpų stebimi aiškių ribų, solidinio tankio, turintys nekrozès zoną centre, susiliejantys konglomeratai iki $13 \times 15,6 \mathrm{~cm}$ ir 9,7x13,5cm dydžio, spaudžiantys plonųjų žarnų kilpas. Dariniai siekia priekinę pilvo sieną, bet jos neperauga. Kairèje pusėje matomas siauras laisvo skysčio ruožas. Kepenys nepadidèjusios. Jose stebimi iki $0,3 \mathrm{~cm}$ hipodensiniai židiniai, dèl mažo dydžio nediferencijuojami. Kasa plona, atrofiška, uodegos srityje iki 2,6 cm dydžio hipodensinis cistinis da-

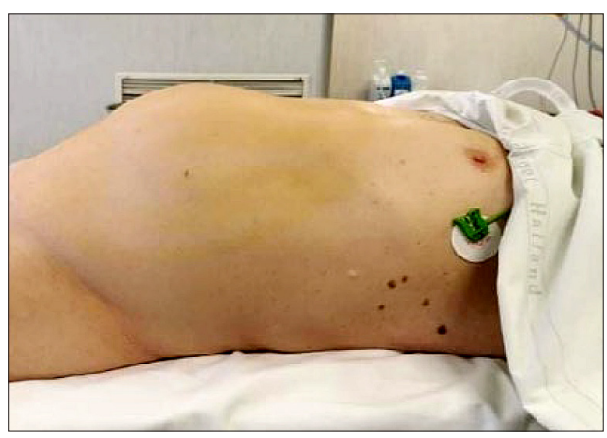

1 pav. Pilvo apimties padidejimas. Darinys pilvo kairèje pusèje

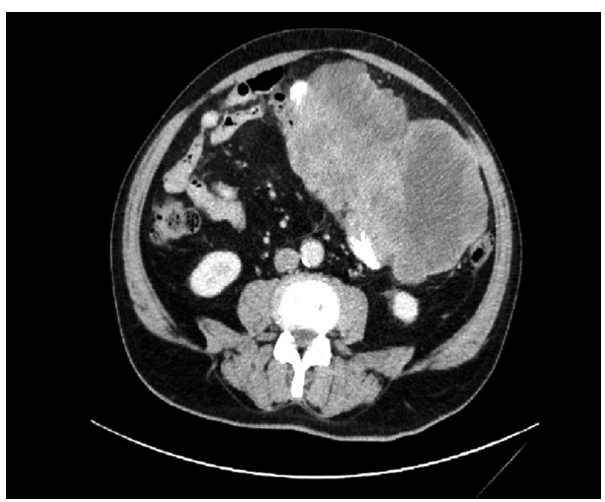

2 pav. Pilvo organų KT prieš operaciją 
rinys, kasos latakas neišplèstas. Inkstai normalaus dydžio, kolektorika neišplèsta, abipus stebimos kelios parenchiminès iki 2,8 cm dydžio cistos. Blužnyje, antinksčiuose, skrandyje KT matomų pakitimų nenustatyta. Pasaite keletas apvalesnių iki $0,8 \mathrm{~cm}$ dydžio limfmazgių. Paraortaliai ir parakavaliai patologinių struktūrų ir padidejusių limfmazgių nematyti. Apimtuose kauluose aiškių destrukcinių pakitimų nematyti.

Radiologo išvada: KT vaizdas panašus ị gastrointestinalinio stromos naviko (GIST) T4 N0/1 M0. Kepenyse smulkūs židinukai dèl mažo dydžio nediferencijuotini, stebėtini dinamikoje. Kasos uodegos ir inkstų cistos (2 pav.).

$2020 \mathrm{~m}$. kovo $16 \mathrm{~d}$. atlikta echoskopu kontroliuojama darinio biopsija. Esant patenkinamai būklei, pacientas išleistas iš ligoninès.

2020 m. balandžio 3 d. dèl pasikartojančių stiprių pilvo skausmų ir žarnyno nepraeinamumo pacientas stacionarizuotas ị KUL pilvo ir endokrininès chirurgijos skyrių. Gautas patohistologinio tyrimo atsakymas, tačiau patologas negalëjo pasakyti kokị naviką mato, todèl nuspręsta ligoni operuoti. Atlikta laparotomija: pilvo ertmėje apie $400 \mathrm{ml}$ ascito, kepe-

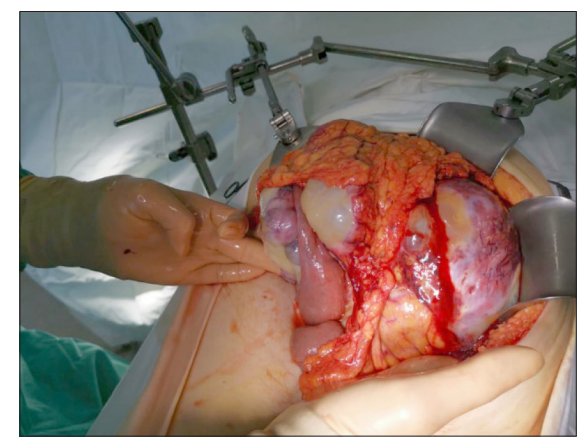

3 pav. Navikas, peraugęs plonosios žarnos kilpas ir skersinę žarną

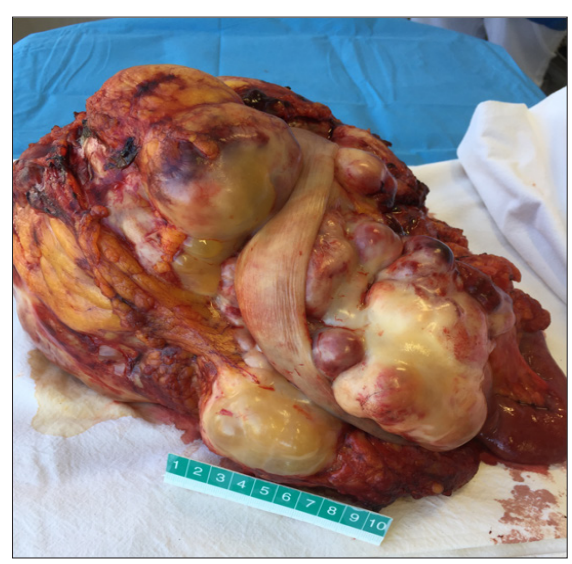

4 pav. Radikaliai pašalintas navikas, 30x20x20 cm dydžio nyse ir kituose organuose metastazių neapčiuopta ir nematyti. Didžiają pilvo dalį užima 30×20x20 dydžio tumoras, nepaslankus, kietas, išaugęs iš pradinès tuščiosios žarnos kilpos. Peraugęs dvylikapirštę žarną, didžiają taukinę, skersinę žarną (3 pav.). Pradejjus iš dešinès, pavyko tumorą atidalinti nuo plonosios žarnos pasaito su arteria mesenterica superior ir vena mesenterica superior, jų nepažeidžiant. Rezekuota skersinè storoji žarna ir nusileidžiančioji storosios žarnos dalis, dvylikapirštès žarnos ketvirtoji dalis ir $60 \mathrm{~cm}$ tuščiosios žarnos. Tumoras, sveriantis apie $5 \mathrm{~kg}$, pašalintas radikaliai (4 pav.). Suformuota jungtis „,̌onas ị šoną“ tarp dvylikapirštès žarnos trečiosios dalies ir tuščiosios žarnos. Suformuota stoma iš kylančiosios storosios žarnos, riestinė žarna užsiūta dviejų aukštų siūlèmis, pilvo ertmė drenuota.

Operacinis preparatas nusiųstas ištirti ị Valstybinị patologijos centrą. Gautas mikroskopinio tyrimo atsakymas: plonosios žarnos sienelejje ir pasaito riebaliniame audinyje yra navikas su infiltraciniais kraštais. Naviką sudaro fibroziniame audinyje netolygiais persipinančiais pluoštais išsidèsčiusios šeivinès ir epitelioidinès fibro-miofibroblastų tipo ląstelès su ovaliais ir pailgais nežymiai polimorfiškais branduoliais, tipinèmis mitozėmis. Navike yra į ganglines ląsteles panašūs stambesni miofibroblastai su ovaliais branduoliais ir gerai

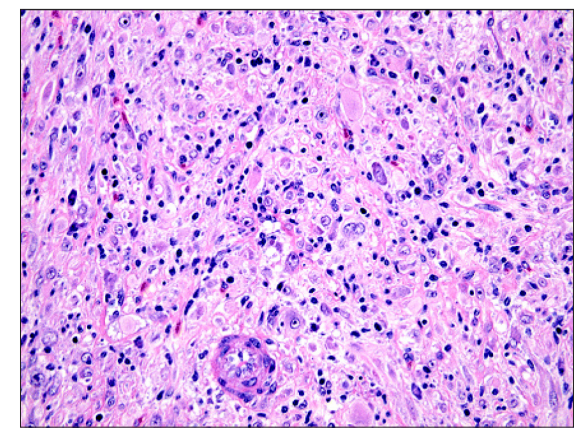

5 pav. Fibrobroblastų-miofibroblastų tipų ląstelès su ovaliais ir pailgais branduoliais

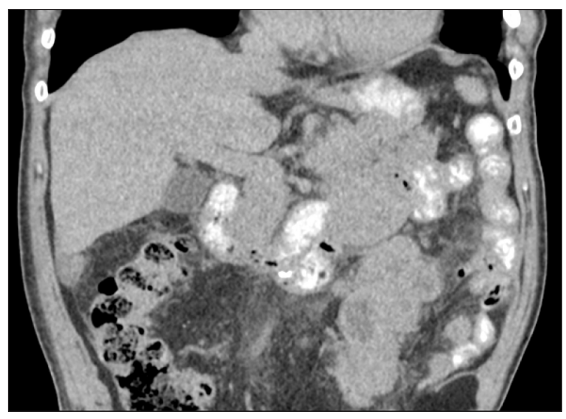

6 pav. Pilvo organų KT 3 mèn. po pirmosios operacijos, daugybinès metastazès pilvo ertmejje 
matomais branduolèliais, mažai ląsteliški, hialinizuoti fibrozinio audinio plotai, miksoidiniai-cistiniai pakitimai, židininè limfoplazmocitine infiltracija su limfoidiniais agregatais, folikulais ir pavieniais eozinofilais (5 pav.). Plonosios žarnos pasaito riebaliniame audinyje tokios pat struktūros naviko židiniai su osteoklastų tipo daugiabranduolèmis gigantinemis ląstelèmis.

Imunohistocheminio tyrimo atsakymas: 100 proc. naviko ląstelių teigiama citoplazminè ir membraninè SMA reakcija, 20 proc. naviko ląstelių teigiama branduolių Ki-67 reakcija. H-caldesmon, Desmin, CD117, DOG1, STAT6, MDM2, CD21, CD23, CD35, ALK1: neigiama ląstelių reakcija.

Pooperacinė eiga buvo sklandi. Ligonis dešimtą pooperacinę parą išleistas ị namus.

2020 m. birželio 4 d. pacientas konsultuotas onkologo, atlikta kontrolinė pilvo organų KT. Joje stebimos daugybinès metastazès pilvo ertmèje ( 6 pav.). Esant metastazinei ligai, pacientas buvo gydomas nesteroidiniais vaistais nuo uždegimo (NVNU), Prednisolonum $30 \mathrm{mg} / \mathrm{d}$, jam paskirta chemoterapija Doxorubycinum ir Ifosfamidum.

2020 m. birželio 11 d. pacientas pakartotinai kreipèsi ị chirurgus dèl pilvo pūtimo ir skausmo. Stoma nefunkcionuoja. Stebetas žarnyno pasažas: kontrastas susilaiko ties distaline dvylikapirštès žarnos dalimi, nustatytas aukštas žarnyno nepraeinamumas. Atlikta laparotomija, suformuota jungtis tarp skrandžio ir tuščiosios žarnos. Operacijos metu stebètas onkologinès ligos progresavimas, dauginiai pilvo ertmès navikai. Pooperacinè būklè sklandi, pacientas pradejjo valgyti. Aštuntą pooperacinę parą išrašytas iš ligoninès.

$2020 \mathrm{~m}$. liepos 17 d. pacientas atvyko pakartotinei onkologo konsultacijai. Ligonio būklè prastejjo, vargino 8 balų intensyvumo pilvo skausmas, išmatuotas vizualinio vertinimo skale. Kasdien didejjo pilvo apimtis dèl navikinio proceso progresavimo. Navikas gigantinio dydžio, užėmė visą kairiają pilvo dalị. Pacientas negalèjo valgyti, vėmé. Stoma funkcionavo gerai. Esant metastazinei ligai, skiriami NVNU, Prednisolonum $30 \mathrm{mg} / \mathrm{d}$. Chemoterapija nedave atsako, o navikas didejo, todèl chemoterapija nutraukta. Skirtas gydymas Pazopanibum. Ligai progresuojant ir pacientui vartojant Pazopanibum, specifinis gydymas toliau netaikomas. Tolesnis gydymas tik simptominis. Po kelių savaičių pacientas mirè.

\section{Diskusija}

UMN yra labai retas navikas, pasitaikantis vienam iš milijono gyventojų. Dažniausiai serga vaikai. Labai retai vyresnio amžiaus žmonès [29]. Tai verpstès formos ląstelių navikas, turintis įvairų uždegiminių ląstelių kiekị, įskaitant plazmos ląsteles, todèl anksčiau vadintas plazmos ląstelių granulioma [21]. UMN etiologiniai veiksniai ir patogenezè nèra gerai žinomi. Manoma, kad UMN atsiradimui ịtakos turi Campylobacter jejuni ir Escherichia coli bakterijos [16]. Kai kurie tyrejjai teigia, jog naviko patogenezei įtakos turi DNR aneuploidija ir ryšys su onkogeniniais virusais, tokiais kaip Epstein-Barr virusas, $H H V-8$ ir per didelè IL-6 ekspresija $[14,15]$. Daugelis tyrimų parodè p80 ekspresiją ir anaplazinès limfomos kinazès (ALK) kloninį persitvarkymą 2p23 chromosomoje, dẻl to kai kurie šių navikų sukelia padidejjusią onkoproteino ekspresiją verpstès formos ląstelèse [8-13].

UMN simptomai nèra specifiniai ir priklauso nuo naviko atsiradimo vietos $[16,17]$. Dažniausia pažeidimo vieta - plaučiai, tačiau galimas ir kitų organų navikas, įskaitant skrandị, pasaitą, taukinę, retroperitoninį tarpą kartu su inkstais, kepenis, blužnị, stemplę ir limfmazgius [5-7,15,16,18]. Esant intraabdominaliniam UMN, pacientai skundžiasi protarpiniu pilvo skausmu ir pilvo apimties didejjimu, svorio mažejjimu, pykinimu, vėmimu. Retais atvejais gali pasireikšti žarnyno nepraeinamumo, invaginacijos ar ūminio pilvo, imituojančio ūmini apendicitą, klinika [17]. Laboratoriniai pokyčiai, tokie kaip anemija, trombocitozè, padidèjęs ENG, hipergamaglobulinemija, nustatomi retai. Pašalinus naviką, buvę simptomai išnyksta, pagerèja laboratoriniai rodikliai [16,20].

Tipinès eigos UMN histopatologiniai radiniai yra ị fasciitą panaši verpstès formos ląstelių proliferacija su miksoidinių ląstelių pokyčiais ir hipoceliuliškumo sritimis [19,20]. Randama įvairių uždegiminių ląstelių, įskaitant poliklonines plazmos ląsteles, limfocitus, eozinofilus, retai - putotų makrofagų [18,22]. Maždaug pusė UMN turi citogenetinę translokaciją, kuri suaktyvina anaplastinès limfomos kinazès receptoriaus tirozino kinazès geną, esanti 2 p23 lokuse, o tai sukelia per didelę ALK baltymo ekspresiją [19]. ALK geno anomalijos lemia ALK1 ir p80 ekspresiją verpstès formos ląstelèse. Tai padeda diagnozuoti ir diferencijuoti šiuos navikus nuo kitų navikų ar ị naviką panašių pažeidimų [21]. Imunohistochemija patvirtina galutinę diagnozę, kai mezenchiminès ląstelès imunoreaktyvios vimentinui, desminui, SMA, S100 baltymui ir neišreiškia CD34 ir CD117 $[12,14,16,17,22]$. Histologiniai požymiai paprastai negali parodyti naviko biologinio aktyvumo, tačiau aneuploidijos buvimas siejamas su agresyvesniu augimu ir didesne naviko recidyvo tikimybe $[11,19]$.

Rekomenduojamas gydymas - visiškas chirurginis naviko pašalinimas $[16,17,23]$. Naviko pasikartojimo tikimybe yra apie $25 \%$, o tolimujų metastazių atsiradimo dažnis $<5$ procentų [28]. Dažniausiai recidyvas stebimas, kai atliekama nevisiška naviko ekstirpacija ir netaikomas chemoterapinis ar radioterapinis gydymas [17]. Nors radioterapija ir chemoterapija gali būti taikoma kaip papildomas gydymo būdas, nèra pakankamai įrodymų apie jų naudą [24,25]. Nesteroidinių vaistų nuo uždegimo nauda prieštaringa [26]. Po chirurgi- 
nio gydymo rekomenduojamas ilgalaikis paciento sveikatos būklès ir jo radiologinių vaizdų stebejjimas $[17,23,27]$.

\section{Išvados}

1. Uždegiminis miofibroblastinis navikas yra ypač retas susirgimas. Dažniausias vaikų kvėpavimo takuose, tačiau randamas ir kitose ịvairaus amžiaus žmonių organų sistemose. Mokslinejje literatūroje aprašyta keletas plonosios žarnos UMN suaugusiems.

2. Dažniausiai ligos eiga gerybinè. Mes aprašėme ypač agresyvios eigos ŪMN klinikinį atvejį.

3. Ši liga diagnozuojama derinant kliniką, laboratorinius ir radiologinius tyrimus, tačiau galutinai patvirtinama imunohistocheminio tyrimo metu. Pagrindinis gydymo būdas yra chirurginis - naviko ekstirpacija.

\section{Literatūra}

1. Day DL, Sane S, Dehner LP. Inflammatory pseudotumor of the mesentery and small intestine. Pediatric Radiol 1986;16: 210-5. https://doi.org/10.1007/BF02456289

2. Malkhlouf HR, Sobin LH. Imflammatory myofibroblastic tumors (inflammatory pseudotumors) of the gastrointestinal tract: How closely are they related to inflammatory fibroid polyps? Hum Pathol 2002; 33: 307-15.

https://doi.org/10.1053/hupa.2002.32213

3. Leuschner I. Inflammatory myofibroblastic tumor. Pathologe 2010; 31: 106-8.

https://doi.org/10.1007/s00292-009-1262-9

4. Bahadori M. Liebow AA. Plasma cell granuloma of the lung. Cancer 1973; 31:191-208.

https://doi.org/10.1002/1097-0142(197301)31:1<191::AIDCNCR2820310127>3.0.CO;2-D

5. Cerfolio RJ, Allen MS, Nascimento AG, Deschamps C, Trastek VF, Miller DL, et al. Inflammatory pseudotumors of the lung. Ann Thorac Surg 1999; 67: 933-6. https://doi.org/10.1016/S0003-4975(99)00155-1

6. Pettinato G, Manivel JC, De Rosa N, Dehner LP. Inflammatory myofibroblastic tumor plasma cell granuloma). Clinicopathological study of 20 cases with immunohistochemical and ultrastructural observations. Am J Clin Pathol 1990: 94: 538-46. 6. https://doi.org/10.1093/ajcp/94.5.538

7. Leon CJ, Castillo J, Mebold J, Cortez L, Felmer R. Inflammatory myofibroblastic tumor of the stomach, an unusual complication after gastrectomy. Gastrointest Endoscopy 2006; 63: 347-9. https://doi.org/10.1016/j.gie.2005.09.026

8. Cessna MH, Zhou H, Sanger WG, Perkins SL, Tripp S, Pickering D, Daines C, Coffin CM. Expression of ALK1 and p80 in inflammatory myofibroblastic tumor and its mesenchymal mimics: a study of 135 cases. Mod Pathol 2002;15: 931-8. https://doi.org/10.1097/01.MP.0000026615.04130.1F
9. Cook JR, Dehner LP, Collins MH, Ma Z, Morris SW, Coffin $\mathrm{CM}$, et al. Anaplastic lymphoma kinase (ALK) expression in the inflammatory myofibroblastic tumor: a comparative immunohistochemical study. Am J Surg Pathol 2001; 25:1364-71. https://doi.org/10.1097/00000478-200111000-00003

10. Snyder CS, Dell'Aquila M, Haghighi P, Baergen RN, Suh YK, Yi ES. Clonal changes in inflammatory pseudotumor of the lung; a case report. Cancer 1995;76:1545-9.

https://doi.org/10.1002/1097-0142(19951101)76:9<1545::AIDCNCR2820760908>3.0.CO;2-H

11. Coffin CM, Patel A, Perkins S, Elenitoba-Johnson KS, Perlman E, Griffin CA. ALK1 and p80 expression and chromosomal rearrangements involving 2p23 in inflammatory myofibroblastic tumor. Mod Pathol 2001; 14: 569-76.

https://doi.org/10.1038/modpathol.3880352

12. Sastre-Garau X, Couturier J, Derré J, Aurias A, Klijanienko J, Lagacé R. Inflammatory myofibroblastic tumor (inflammatory pseudotumour) of the breast. Clinicopathological and genetic analysis of a case with evidence for clonality. J Pathol 2002; 196: 97-102. https://doi.org/10.1002/path.1004

13. Lawrence B, Perez-Atayde A, Hibbard MK, Rubin BP, Dal Cin P, Pinkus JL, et al. TPM3-ALK and TPM4-ALK oncogenes in inflammatory myofibroblastic tumors. Am J Pathol 2000;157: 377-84. https://doi.org/10.1016/S0002-9440(10)64550-6

14. Park SH, Kim JH, Min BW, Song TJ, Son GS, Kim SJ, et al. Exophytic inflammatory myofibroblastic tumor of the stomach in an adult woman: a rare cause of hemoperitoneum. World J Gastroenterol 2008;14:136-9.

https://doi.org/10.3748/wjg.14.136

15. Attili SV, Chandra CR, Hemant DK, Bapsy PP, RamaRao C, Anupama G. Retroperitoneal inflammatory myofibroblastic tumor. World J Surg Oncol 2005;3:66.

https://doi.org/10.1186/1477-7819-3-66

16. Oeconomopoulou A, de Verney Y, Kanavaki K, Stefanaki K, Pavlakis K, Salakos C. Inflammatory myofibroblastic tumor of the small intestine mimicking acute appendicitis: a case report and review of the literature. Journal of Medical Case Reports. BioMed Central; 2016. https://www.ncbi.nlm.nih.gov/pmc/ articles/PMC4837596/

https://doi.org/10.1186/s13256-016-0880-0

17. Cerier E, Beal EW, Dillhoff ME. Inflammatory myofibroblastic tumour: an unusual presentation including small bowel obstruction and palpable abdominal mass. BMJ Case Rep. 2018;2018:bcr-2018-224549.

https://doi.org/10.1136/bcr-2018-224549

18. Karnak I, Senocak ME, Ciftci AO, Cağlar M, Bingol-Koloğlu $\mathrm{M}$, Tanyel FC, et al. Inflammatory myofibroblastic tumor in children: diagnosis and treatment. J Pediair Surg 2001; 36: 908-12.

https://doi.org/10.1053/jpsu.2001.23970 
19. Surabhi VR, Chua S, Patel RP, Takahashi N, Lalwani N, Prasad SR. Inflammatory myofibroblastic tumors: current update. Radiol Clin North Am 2016;54(3):553-63.

https://doi.org/10.1016/j.rcl.2015.12.005

20. Gleason B, Hornick J. Inflammatory myofibroblastic tumors: where are we now? J Clin Pathol 2008; 61: 428-37, https://doi.org/10.1136/jep.2007.049387

21. Alabbas Z, Issa M, Omran A, Issa R. Mesenteric inflammatory myofibroblastic tumor as a rare cause of small intestinal intussusception. J Surg Case Rep 2020;2020(9):rjaa322. https://doi.org/10.1093/jscr/rjaa322

22. Coffin CM, Watterson J, Priest JR, Dehner LP. Extrapulmonary inflammatory myofibroblastic tumor (inflammatory pseudotumor). A clinicopathologic and immunohistochemical study of 84 cases. Am J Surg Pathol 1995;19:859-72. https://doi.org/10.1097/00000478-199508000-00001

23. Spencer H. The pulmonary plasma cell / histiocytoma complex. Histopathology 1984; 8: 903-16. https://doi.org/10.1111/j.1365-2559.1984.tb02409.x

24. Dishop MK, Warner BW, Dehner LP, Kriss VM, Greenwood MF, Geil JD, et al. Successful treatment of inflammatory myofibroblastic tumor with malignant transformation by surgical resection and chemotherapy. J Pediatr Hematol 2003; 25: 153-8. https://doi.org/10.1097/00043426-200302000-00014

25. Hagenstad CT, Kilpatrick SE, Pettenati MJ, Savage PD. Inflammatory myofibroblastic tumor with bone marrow involvement. A case report and review of the literature. Arch Pathol Lab Med 2003;127: 865-77.

26. Sanders BM, West KW, Gingalewski C, Engum S. Davis M, Grosfeld JL. Inflammatory pseudotumor of the alimentary tract: clinical and surgical experience. J Pediatr Surg 2001; 36: 169-73. JL.

https://doi.org/10.1053/jpsu.2001.20045
27. Amouei A, Ehsani F, Vaghefi M, Tabatabai SM, Yazdian Anari P. Inflammatory myofibroblastic tumor of the small intestine: a case report. Int J Surg Case Rep 2016;22:44-6. https://doi.org/10.1016/j.ijscr.2016.03.025

28. Koyuncuer A. Inflammatory myofibroblastic tumor of the small-bowel mesentery: a case report of nonspecific clinical presentation and a review of the literature. Int J Surg Case Rep 2014;5(12):1214-7. https://doi.org/10.1016/j.ijscr.2014.11.054

29. Panagiotopoulos N, Patrini D, Gvinianidze L, Woo WL, Borg E, Lawrence D. Inflammatory myofibroblastic tumour of the lung: a reactive lesion or a true neoplasm? J Thorac Dis 2015;7(5):908-911.

\section{INFLAMMATORY MYOFIBROBLASTIC TUMOUR OF THE SMALL INTESTINE: A CASE REPORT G. Viederytė, A. Šlepavičius}

Key words: inflammatory myofibroblastic tumour, inflammatory myofibroblastic tumour of the small intestine, surgery

Summary

Inflammatory myofibroblastic tumour (IMT) is a rare neoplastic lesion with local aggressive behaviour and has tendencies in recurrence. The tumour most commonly occurs in children's respiratory tract, although it can damage any organ. The gastrointestinal tract rarely is the primary site of origin. Symptoms are non-specific and depend on the location of the tumour. In this case report, we will present a 71-year-old male with a primary inflammatory myofibroblastic tumour of the small intestine with symptoms of intestinal obstruction.

Correspondence to: g.viederyte@gmail.com

Gauta 2020-12-01 